結腸・直腸穿孔 37 症例の臨床的検討

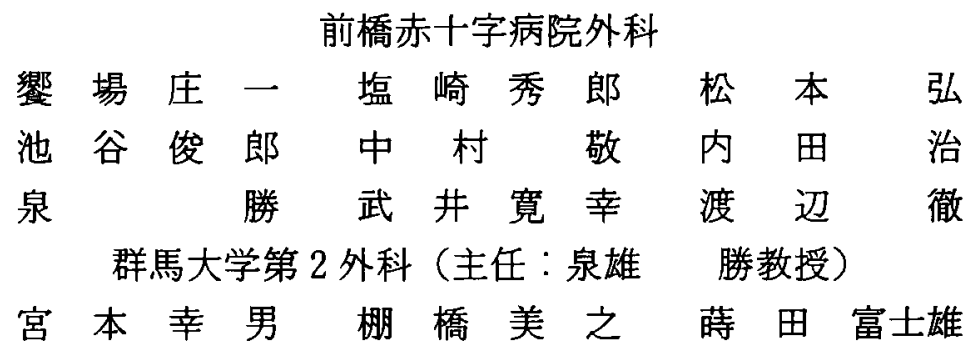

結腸・直腸穿孔の頻度は上部消化管穿孔の頻度と比べれば極く少ない，しかしその穿 孔の原因・誘因・発生部位などは多様で，乙かも䔬便性腹膜炎であるなど重篤な例が多 い.

著者らは昭和 45 年 4 月以来 19 年間に経験した 37 例を原因別に診断と治療経過・予後な どを検討した．特発性穿孔とした10例の中には毠室穿孔と思われる例や排便・怒責後に 発症した高齢者の 4 例がある。続発性穿孔の10例には結腸・直腸癌の 4 例，腸閉塞によ る 3 例や潰瘍性大腸炎・直腸子宮内膜症穿孔など極く稀な 2 例がある．外傷性穿孔は 17 例で一般外傷の 8 例, 医原性の 9 例が含まれる。1 症例平均 2.5 種の菌による複数菌感染 であることが治療を難涉させ死亡率を高くしている，同期間に和ける他部位での消化管 穿孔例の死亡率とも比較した。さらに内外の文献について広く考察を行った。

索引用語：結腸 - 直腸穿孔，宿便性穿孔，息室穿孔，直腸子宮内膜症穿孔，潰鈞性大腸穿孔

\section{緒 言}

急性腹症として重要な位置を占める消化管穿孔のな かで，結腸・直腸穿孔の頻度は胃・十二指腸・小腸な どの穿孔例の頻度と比べれば極くすくない，しかしな がら結腸・直腸穿孔の原因・誘因・発生部位等は多様 で，しかも重篤な䔬便性腹膜炎を起こして, enndotoxin shock, DIC，MOF などへ移行するなど治療に難沾 する例が多い，そこで自験例を原因別に検討するとと もに，同期間に経験した他部位での消化管穿孔例での 死亡率とも比較した。さらに内外の文献について考察 を行った。

\section{研究対象およひ方法}

昭和 45 年 4 月以来著者らが経験した結腸・直腸穿孔 性腹膜炎37例を対象として，その原因別に症例の診断 と治療経過・予後などを検討した。

$$
\text { 成 績 }
$$

\section{I. 原因別検討}

結腸・直腸穿孔の原因・誘因別の分類法には色々の
試みがある。とくに特発性として分類されたものには， 欧米で宿便性穿孔 stercoraceous perforation として の報告もあるが憩室がその原因と考えられるものも含 まれているよ5に，な打不明の症例も実際には経験さ れる。そこで今回は従来の分類法に従って特発性・続 発性・外傷性の 3 つに大別した。

1）特発性結腸・直腸穿孔

肉眼的に病変や外傷など原因が確定できないものが

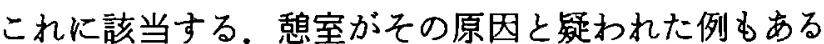
が，な敃確認できなかったので便宜的にこの項に加光 た。症例は10例である（表 1)。

症例 2 の 48 歳の男性 1 例以外は63藏から83藏で平均 年齢は72歳で比較的高龄者で占められている. 症例 4 ・66歳と症例 9 ・63歳数室壁の穿孔が疑われた女性 の 2 例以外は総べて男性である。この症例 4 はS 状結 腸穿孔部分の製状切除による閉鎖縫合術であるが，手 術後の注腸造影で下行結腸からS 状結腸に慗室が多 発していた。症例 8 ・33歳男性では切除標本の組織診 断から秝室が疑われた。症例7.76歳男性では直腸の腹 膜翻転部から上 $10 \mathrm{~cm}$ の部位に $2.5 \mathrm{~cm} \times 2.0 \mathrm{~cm}$ の穿孔 
表 1 特発性結腸・直腸穿孔・破裂の症例

\begin{tabular}{|c|c|c|c|c|c|c|c|c|}
\hline 氏名 $\begin{array}{c}\text { 年 } \\
\text { 踚 } \\
\text { (㗤) }\end{array}$ & 手 術 診 断 & 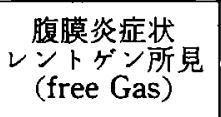 & \begin{tabular}{|c|} 
発症 \\
手術 \\
(時間)
\end{tabular} & $\underset{(\mathrm{mmHg})}{\text { 血 }}$ & $\underset{(\mathrm{g} / \mathrm{dl})}{\mathrm{TP}}$ & $\begin{array}{c}W \\
\left(\times 10^{3}\right)\end{array}$ & 手術方法 & 予 後 \\
\hline$\stackrel{(1)}{\mathrm{K} . \mathrm{H} .} \underset{(47.12 .)}{66}{ }^{\text {男 }}$ & $\begin{array}{l}\mathrm{S} \text { 状結腸穿孔(排便後腹痛) } \\
\text { 腸間膜寄り }(1 \times 1.5 \mathrm{~cm})\end{array}$ & $\begin{array}{c}\text { (卅) } \\
\text { 腸閉塞? }\end{array}$ & 20 & $\frac{100}{20}$ & 6.0 & 12.5 & $\begin{array}{c}\text { 閉鎖術 } \\
\text { 人工肛門 }\end{array}$ & $\begin{array}{c}\text { 術後 } 5 \text { 日 } \\
\text { 死亡 }\end{array}$ \\
\hline$\stackrel{(2)}{\text { K. K. }}{ }_{(48.12 .)}^{48}{ }^{\text {男 }}$ & $\begin{array}{l}\text { S 状結腸穿孔 } \\
\text { (小指頭大) }\end{array}$ & $\begin{array}{l}(+) \\
(-)\end{array}$ & 6 & $116 / 76$ & 6.1 & 10.3 & $\begin{array}{c}\text { 閉鎖術 } \\
\text { 人工工肛門 }\end{array}$ & $\begin{array}{c}\text { 入院25日 } \\
\text { 生存 }\end{array}$ \\
\hline 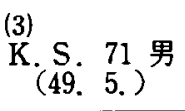 & $\begin{array}{l}\mathrm{S} \text { 状結腸穿孔(排便後腹痛) } \\
\mathrm{S}-\mathrm{M} \text { 欠損 }(3 \times 4 \mathrm{~cm}) \text { 小穿孔 } 1 \text { = }\end{array}$ & $\begin{array}{l}(+) \\
(+)\end{array}$ & 52 & $\frac{130}{80}$ & 5.8 & 11.2 & 切除術 & $\begin{array}{c}\text { 入院 } 46 \text { 日 } \\
\text { 生存 }\end{array}$ \\
\hline$\underset{(54 .}{\text { 7. })}{ }^{\text {M. S) }}$ & $\begin{array}{l}\text { S 状結腸穿孔 } \\
\text { 前譬 }(0.1 \times 0.1 \mathrm{~cm}) \text { (㮩室壁) } \\
\text { 梧病 }\end{array}$ & $\begin{array}{l}(H) \\
(-)\end{array}$ & 7 & $150 / 90$ & 6.4 & 13.6 & 閉鎖術 & $\begin{array}{c}\text { 入院 } 21 \text { 日 } \\
\text { 生存 }\end{array}$ \\
\hline$\stackrel{\text { (5) }}{\text { T.K. }} .74$ 男 $_{(57.10 .)}$ & $\begin{array}{l}\text { S 状結腸穿孔 } \\
\text { 前壁 }(3 \times 3 \mathrm{~cm})\end{array}$ & $\begin{array}{l}(+1+) \\
(+)\end{array}$ & 15 & $\begin{array}{c}\frac{74}{48} \\
{[\text { リムルス }} \\
\end{array}$ & 4.9 & 2.5 & $\begin{array}{l}\text { 閉鎖術 } \\
\text { 盲腸瘦 }\end{array}$ & $\begin{array}{c}\text { 術後 } 3 \text { 日 } \\
\text { 死亡 }\end{array}$ \\
\hline$\left.\stackrel{(6)}{Y} \cdot{ }_{(57.11 .)}{ }^{71}\right)^{\text {男 }}$ & $\begin{array}{l}S \text { 状結腸穿孔 } \\
\text { 前壁 }(2 \times 3 \mathrm{~cm})\end{array}$ & $\begin{array}{l}(+1) \\
(+)\end{array}$ & 6 & $\begin{array}{c}\text { 鳋診 } \\
{[\text { (リムルス }} \\
\end{array}$ & 5.1 & 3.7 & $\begin{array}{c}\text { 閉鎖術 } \\
\text { 人工肛門 }\end{array}$ & $\begin{array}{c}\text { 術後 } 1 \text { 日 } \\
\text { 死亡 }\end{array}$ \\
\hline $\begin{array}{l}\text { (7) } \\
\text { M.S. } 76 \text { 男 } \\
(59.6 .)\end{array}$ & $\begin{array}{l}\text { 直腸穿孔(排便後腹痛) } \\
\text { (腹膜魏転部上 } 10 \mathrm{~cm} に 2.5 \times 2.0 \mathrm{~cm} \text { ) }\end{array}$ & $\begin{array}{l}(+) \\
(-)\end{array}$ & 12 & $\frac{140}{86}$ & 6.7 & 15.9 & $\begin{array}{l}\text { 閉鎖術 } \\
\text { 盲腸痋 }\end{array}$ & $\begin{array}{c}\text { 入院54日 } \\
\text { 生存 }\end{array}$ \\
\hline $\begin{array}{l}(8) \\
\text { S.Y. Y. } \\
(60.1 .)^{8}\end{array}$ & $\begin{array}{l}\mathrm{S} \text { 状結腸穿孔(梸室) } \\
\text { 結腸間膜対側 }(1.0 \times 0.7 \mathrm{~cm})\end{array}$ & $\begin{array}{l}(H) \\
(H)\end{array}$ & 6 & $\frac{148}{82}$ & 6.1 & 3.6 & $\begin{array}{l}\text { 切除術 } \\
\text { 盲腸瘦 }\end{array}$ & $\begin{array}{c}\text { 入院30日 } \\
\text { 生存 }\end{array}$ \\
\hline$\stackrel{\text { M) }}{\text { M. S. }}{ }_{(63.10 .)}$ 女 & 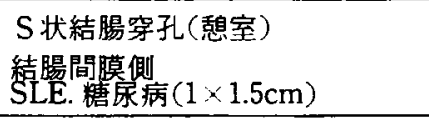 & $\begin{array}{l}(+) \\
(+)\end{array}$ & 70 & $\frac{80}{60}$ & 6.1 & 6.8 & 切除術 & $\begin{array}{c}\text { 入院128日 } \\
\text { 生存 }\end{array}$ \\
\hline${ }_{(63.10 .)}^{(10)}$ & $\begin{array}{l}\text { S 状結腸第孔(賏室) } \\
\text { 結腸間膜対側 }\end{array}$ & $\begin{array}{l}(+) \\
(-)\end{array}$ & 96 & $\begin{array}{c}\frac{118}{70} \\
{[\text { (1) ムルス }(-)]}\end{array}$ & 5.9 & 18.0 & $\begin{array}{c}\text { 切除術 } \\
\text { 胃癭造設 }\end{array}$ & $\begin{array}{c}\text { 術後 } 9 \text { 日 } \\
\text { 死亡 }\end{array}$ \\
\hline
\end{tabular}

を認めた．この例以外は総べて S 状結腸穿孔であっ た。症例 $1 \cdot 66$ 歳, 症例 $3 \cdot 71$ 歳, 症例 $7 \cdot 76$ 歳, 症 例 $8 \cdot 83$ 歳の 4 例は排便時の怒責後に腹痛で発症して いる．欧米の報告にみる宿便性穿孔に該当するが，穿 孔の機序・原因が，なお不明でもありこの項にいれた。 診断的にはどの症例も腹膜炎症状が明らかである. レントゲン的に腹腔内遊離ガス像陽性は 10 例中 5 例で ある。発症から手術までの時間は $6 \sim 7$ 時間が 4 例, 半日前後か 2 例， 1 日程度 1 例， 2 日以上が 3 例であ る。死亡は 10 例中 4 例 (40\%) で症例 1 は術後 5 日， 症例 5 は術後 3 日, 症例 6 は翌日, 症例10は術後 9 日 で失った。血清蛋白濃度は全例で低く、ショックある いはショック準備状態にあり，白血球増多のみられな い例もあった。

治療的には全身状態中高齢者であることも考虑して 穿孔部分の単純閉鎖術か切除術と腹膜炎に対して十分 な洗浄と誘導である。穿孔部のより口側に人工肛門造 設, あるいはWitzel 式の盲腸瘦を安全弁として造る
などは有効な処置であり， Nelatonカテーテルの拔去 で膺孔は自然治瘜した。

2）続発性結腸・直腸穿孔

腸管壁に癌その他の病変があって穿孔の起こった症 例が本来である。しかし腸管壁自体に先行する病変が なくても軸捻転や絞扼性イレゥスなどが原因となって 二次的に穿孔を起こした例もこの項にいれた。自験例 は10例である（表 2).

(a) 癌に上る穿孔

結腸癌直腸癌の穿孔は 4 例である。症例 2 は79歳女 性の上行結腸癌狭窄に上る盲腸穿孔. 症例 7 は30歳女 性の直腸癌での直腸穿孔, 症例 8 は53歳男性の横行結 腸癌・肝臓転移例での盲腸穿孔。症例 9 は64歳男性の $\mathrm{S}$ 状結腸癌㹨窄に上る $\mathrm{S}$ 状結腸穿孔である。癌による 㹟窄部より口側での穿孔と癌浸潤部での穿孔がある.

（b）腸閉塞（鎖肛・捻転など）による穿孔

症例 1 は鎖肛に気ずかず, 生後 3 日目に腹膜炎で紹 介されて手術を行った S 状結腸穿孔例である。症例 4 
表 2 続発性結腸・直腸穿孔の症例

\begin{tabular}{|c|c|c|c|c|c|c|c|c|}
\hline $\begin{array}{l}\text { 年 } \\
\text { 氏名 龄 性 } \\
\text { (歳) }\end{array}$ & 手 術 診 断 & $\begin{array}{l}\text { 腹膜炎症状 } \\
\text { 年ゲン所見 } \\
\text { (free Gas) }\end{array}$ & $\begin{array}{l}\text { 発症 } \\
\text { 手術 } \\
\text { (時間) }\end{array}$ & $\underset{(\mathrm{mmHg})}{\text { 血 }}$ & $\underset{(\mathrm{g} / \mathrm{dl})}{\mathrm{TP}}$ & $\begin{array}{c}\mathrm{W} \\
\left(\times 10^{3}\right)\end{array}$ & 手術方法 & 予 後 \\
\hline $\begin{array}{l}\text { (1) } \\
\text { K. H. 生後男 } \\
\text { (47.9. })\end{array}$ & $\begin{array}{l}\text { 鎖肛 } \\
\mathrm{S} \text { 状結腸穿孔性腹膜炎 }\end{array}$ & $\begin{array}{l}(\text { (H) } \\
(\text { (H) }\end{array}$ & 6 & & & & $\begin{array}{l}\text { 閉鎖術 } \\
\text { 人工肛門 }\end{array}$ & $\begin{array}{c}\text { 入院25日 } \\
\text { 生存 }\end{array}$ \\
\hline$\stackrel{(2)}{\text { T. I. }} \underset{(51.9 .)}{79}$ 女 & $\begin{array}{l}\text { 盲腸穿孔 }(1.0 \times 1.0 \mathrm{~cm}) \\
\text { (上行結腸癌狭窄 })\end{array}$ & $\begin{array}{l}(H) \\
(+)\end{array}$ & 8 & $70 / 40$ & 6.1 & 3.0 & $\begin{array}{l}\text { 閉鎖術 } \\
\text { 人工肛門 }\end{array}$ & $\begin{array}{c}\text { 術後 } 44 \text { 日 } \\
\text { 死亡 }\end{array}$ \\
\hline $\begin{array}{l}\text { H. } \\
\text { H. A. } \\
\text { (57.9.) }\end{array}$ & $\begin{array}{l}\text { 上行結腸穿孔・膿瘍形成・ } \\
\text { イレウウ } \\
\text { 潰瘍性大腸炎 }\end{array}$ & $\begin{array}{c}\text { (H) } \\
\text { イレゥス }\end{array}$ & 2 力月 & $114 / 90$ & 5.6 & 37.4 & 楔状切除 & $\begin{array}{c}\text { 入院68日 } \\
\text { 生存 }\end{array}$ \\
\hline$\stackrel{(4)}{\mathrm{S} . \mathrm{Y} .{ }_{(58.7 .)}^{71}}$ & $\begin{array}{l}\mathrm{S} \text { 状結腸捻転・穿孔 } \\
\text { 尿閉(前立腺肥大) } ・ \text { 膀胱瘦 }\end{array}$ & $\begin{array}{l}\text { (H) } \\
(\text { (H) }\end{array}$ & 30 & $100 / 65$ & 5.5 & 2.4 & ハルトマン手術 & $\begin{array}{c}\text { 術後27日 } \\
\text { 死亡 }\end{array}$ \\
\hline 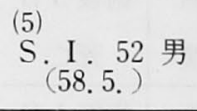 & $\begin{array}{l}\text { 盲腸穿孔 } \\
30 \text { 年前回腸・横行結腸吻会 } \\
1 \text { 年前ハ, } \text { 置) }\end{array}$ & $\begin{array}{l}(H) \\
(+)\end{array}$ & 34 & $98 / 64$ & 6.9 & 8.5 & 結腸右半切除 & $\begin{array}{c}\text { 入院38日 } \\
\text { 生存 }\end{array}$ \\
\hline $\begin{array}{l}\text { (6) } \\
\text { K. K44 女 } \\
\text { (58.3.) }\end{array}$ & $\begin{array}{l}\text { 直腸穿孔 } \\
\text { 直腸子宮内膜症 }\end{array}$ & $\begin{array}{l}(+) \\
(-)\end{array}$ & 8 & $90 / 50$ & 6.0 & 12.5 & ハルトマン手術 & $\begin{array}{c}\text { 入院40日 } \\
5 \text { 力後 } \\
\text { 低位前切除 }\end{array}$ \\
\hline$\stackrel{(7)}{Y} \cdot \frac{S}{(58.6 .)}{ }^{30}$ 女 & $\begin{array}{l}\text { 直腸穿孔 } \\
\text { 直腸癌 }\end{array}$ & $\begin{array}{l}(H) \\
(+)\end{array}$ & 30 & $120 / 80$ & 8.0 & 15.0 & $\begin{array}{c}\text { 誘導 } \\
\text { 人工肛門 }\end{array}$ & $\begin{array}{l}\text { 入院30日 } \\
11 \text { 月後 } \\
\text { 再入院亡 }\end{array}$ \\
\hline$\stackrel{(8)}{\text { S.I. }} \underset{(59.1 .)}{ } 53$ 男 & $\begin{array}{l}\text { 盲腸穿孔 } \\
\text { 横行結腸癌・肝転移 }\end{array}$ & $\begin{array}{l}(+) \\
(H)\end{array}$ & 4 & $118 / 80$ & 5.2 & 8.8 & $\begin{array}{l}\text { 横行結腸切除 } \\
\text { 肝部分切除 } \\
\text { 盲腸瘦 }\end{array}$ & $\begin{array}{c}\text { 入院 } 47 \text { 日 } \\
\text { 生存 }\end{array}$ \\
\hline$\stackrel{(9)}{\text { T. I. }} \underset{(59.9 .)}{64 \text { 男 }}$ & $\begin{array}{l}\mathrm{S} \text { 状結腸穿孔 } \\
\mathrm{S} \text { 状結腸癌の狭窄 }\end{array}$ & $\begin{array}{l}(H) \\
(-)\end{array}$ & 6 & $120 / 84$ & 6.2 & 10.8 & $\mathrm{~S}$ 結腸切除 & $\begin{array}{c}\text { 入院 } 60 \text { 日 } \\
\text { 生存 }\end{array}$ \\
\hline$\stackrel{(10)}{\mathrm{K} .}$ (元. ${ }^{7 .}$ ) & $\begin{array}{l}\mathrm{S} \text { 状結腸穿孔(賏室) } \\
\mathrm{S} \text { 状結腸癌(Rectosiqmoid) }\end{array}$ & $\begin{array}{l}(+) \\
(+)\end{array}$ & 8 & $80 /$ & 6.2 & 9.6 & 前方切除 & $\begin{array}{c}\text { 入院 } 60 \text { 日 } \\
\text { 生存 }\end{array}$ \\
\hline
\end{tabular}

は71歳男性, 前立腺癌による尿閉で泌尿器科で膀胱瘦 造設術後16日目に腹痛が出現した。レントゲン的に遊 離ガス陽性から穿孔性腹膜炎の診断で開腹すると， S 状結腸捻転が原因で穿孔していた。

症例 5 は 30 年前に腸閉塞で回腸・横行結腸吻合術が 行われており，1年前にも腸閉塞でパイパス手術が行 われている，そして今回の手術となった例で盲腸が穿 孔していた，前 2 回の手術は他院であるが，空置され ていた部分を含めて右半結腸切除術を行った。

（c）稀な原因（潰掦性大腸炎・直腸子宮内膜症など） に上る穿孔

症例 6 は44歳女性で急性腹膜炎の診断で開腹した。 局所所見から直腸癌の穿孔とみて Hartomann 手術を 行った，組織学的に（図 1) 直腸子宮内膜症による穿 孔と診断された稀な例である。 5 力月後に再入院して 人工肛門の解除・腹腔内吻合を行った。

症例 3 は35歳男性の潰瘍性大腸炎による穿孔例であ

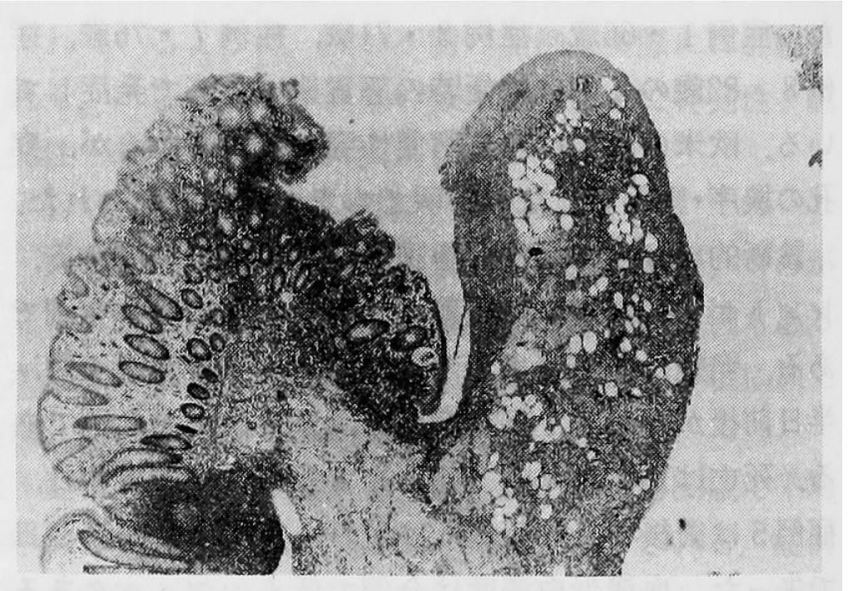

図 1 症例 6 組織像：直腸壁の固有筋層深部扣よび絨 維性肉芽性に肥厚した嶈膜下織内に子宮内膜が認め られ，槳膜下に出血を伴っている（H.E.染色 $\times 22 ）$.

る５月18日，ジャワ島で発病して州国したために， 先ずマラリヤとしてキニーネによる治療で始まってい 
る.無顆粒球血症，さらにDICを疑われた。7月18日 に下血・発熱・腹痛で全身状態不良となって当科入転 院してきた，来院時，腹痛と嘔気が強く，血圧114/90 $\mathrm{mmHg}$, 脈拍数 120 , 白血球数 37,400 , 腹部膨満強く, デファンス陽性, レントゲン的に腸閉塞状態のため緊 急手術を行った。上行結腸と横行結腸に大網膜の強い 瘾着による腫瘤がある。これを䐣離するとその部は穿 孔による膿湯形成で，そのための腸閉塞と思われた。 組織学的（図 2) には潰場性大腸炎の穿孔と診断され た，潰揚性大腸炎の大腸穿孔も稀な症例である。

続発性穿孔に対する治療法としては原疾患が癌をは じめ腸管壁に原因があっての穿孔であるので，切除術 が望ましいが全身状態から穿孔部の縫合閉鎖と人工肛 門造設や腸瘦造設に終わることも救命手段として致し 方ない場合もある．この項での手術直接死亡は10例中 2 例である。

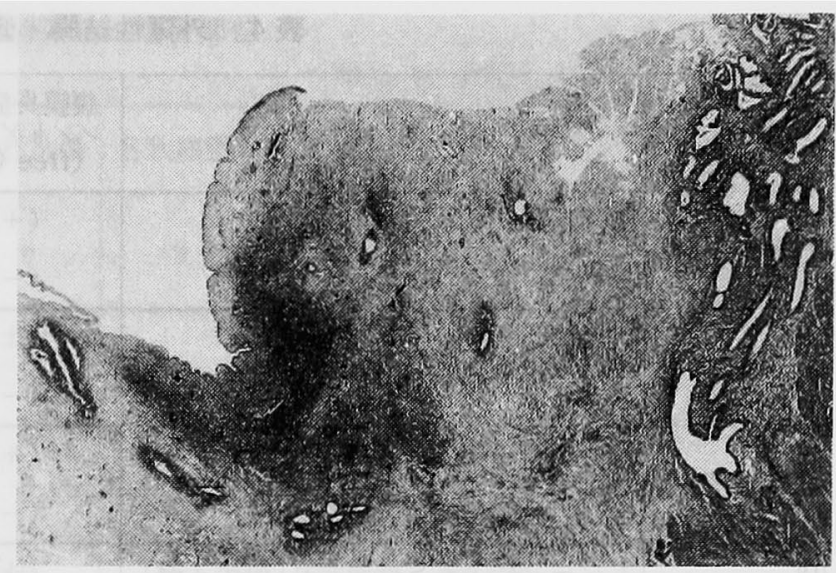

図 2 症例 3 組織像：穿孔性潰瘍と腹膜炎をきたした 大腸組織で，潰瘍周囲の粘膜には陰窩膿瘍をみとめ る（H.E.染色 $\times 34 ）$

3）外傷性結腸・直腸穿孔

自験17例を表 3 ・4 に示した。一般的な外傷の他に

表 3 外賃性結腸・直腸穿孔・破裂の症例（1）

\begin{tabular}{|c|c|c|c|c|c|c|c|c|}
\hline $\begin{array}{l}\text { 年 } \\
\text { 氏名 龄 性 } \\
\text { (歳) }\end{array}$ & 手 術 診 断 & $\begin{array}{l}\text { 腹膜炎症状 } \\
\text { レド所見 } \\
\text { (free Gas) }\end{array}$ & $\begin{array}{l}\text { 発症 } \\
\text { 手術 } \\
\text { (時間) }\end{array}$ & $\begin{array}{c}\text { 血压 } \\
(\mathrm{mmHg})\end{array}$ & $\begin{array}{c}\mathrm{TP} \\
(\mathrm{g} / \mathrm{dl})\end{array}$ & $\begin{array}{c}\mathrm{W} \\
\left(\times 10^{3}\right)\end{array}$ & 手術方法 & 予 後 \\
\hline 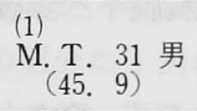 & $\begin{array}{l}\text { 外傷性直腸 } \cdot S \text { 状結腸 } \\
\text { 刺創 }\end{array}$ & $\begin{array}{l}(+) \\
(-)\end{array}$ & 3 & $92 / 70$ & 6.8 & 11.6 & $\begin{array}{l}\text { 閉鎖術 } \\
\text { 誘導 }\end{array}$ & $\begin{array}{c}\text { 入院31日 } \\
\text { 生存 }\end{array}$ \\
\hline$\stackrel{(2)}{\text { K. A. } 19}$ 男 & $\begin{array}{l}\text { 外傷性直腸・膀胱 } \\
\text { 刺創 }\end{array}$ & $\begin{array}{l}(+) \\
(-)\end{array}$ & 6 & $130 / 60$ & 6.5 & 19.1 & $\begin{array}{l}\text { 閉鎖術 } \\
\text { 誘導 }\end{array}$ & $\begin{array}{c}\text { 入院38日 } \\
\text { 生存 }\end{array}$ \\
\hline 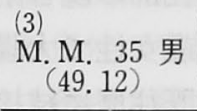 & $\begin{array}{l}\text { 外傷性 S 状結腸 S - M 欠損 } \\
\text { 空腸穿孔・肝破裂・下腿骨折 }\end{array}$ & $\begin{array}{l}(+) \\
(+)\end{array}$ & 6 & $120 / 100$ & 5.6 & 12.4 & $\begin{array}{l}\text { 閉鎖術 } \\
\text { 誘導 }\end{array}$ & $\begin{array}{c}\text { 入院 } 25 \text { 日 } \\
\text { 生存 }\end{array}$ \\
\hline $\begin{array}{l}\text { (4) } \\
\text { S. I. } 42 \text { 女 } \\
\text { (50. 9) }\end{array}$ & $\begin{array}{l}\text { 外傷性横行結腸 S - M欠損 } \\
\text { 空腸穿孔 ( } 3 \text { 力所) }\end{array}$ & $\begin{array}{l}(H) \\
(-)\end{array}$ & 7 & $140 / 90$ & 6.4 & 6.0 & $\begin{array}{l}\text { 切除術 } \\
\text { 誘導 }\end{array}$ & $\begin{array}{c}\text { 入院 } 12 \text { 日 } \\
\text { 生存 }\end{array}$ \\
\hline $\begin{array}{l}\text { (5) } \\
\text { R.I. } 75 \text { 男 } \\
\text { (52.7) }\end{array}$ & 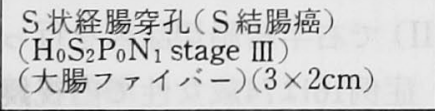 & $\begin{array}{l}\text { (H) } \\
(H)\end{array}$ & 3 & $105 / 70$ & 5.1 & 10.8 & $\begin{array}{c}\text { 閉銷術 } \\
\text { 人工恠 } \\
\text { 誘導 }\end{array}$ & $\begin{array}{c}\text { 術後 } 40 \text { 日 } \\
\text { 生存 }\end{array}$ \\
\hline $\begin{array}{l}\text { (6) } \\
\text { R.I. } 76 \text { 男 }\end{array}$ & $\begin{array}{l}\text { 前症例 } 9 \text { カ月後 } \\
\text { 浣腸 (自宅)の失敗で穿孔 }\end{array}$ & $\begin{array}{l}(H) \\
(+)\end{array}$ & 5 & $140 / 108$ & 5.6 & 15.5 & $\begin{array}{c}\text { 閉鎖術 } \\
\text { 誘導 }\end{array}$ & $\begin{array}{c}\text { 術後 } 7 \text { 日 } \\
\text { 死亡 }\end{array}$ \\
\hline 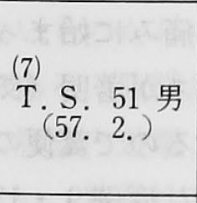 & $\begin{array}{l}\text { 外傷性 S 状結腸破裂・空腸破裂 } \\
\text { ( 回盲動脈切断・骨盤骨折 }\end{array}$ & $\begin{array}{l}(+) \\
(+)\end{array}$ & 7 & $90 / 60$ & 6.2 & 15.3 & $\begin{array}{l}\text { 回盲部 } \\
\text { 空腸切除 }(1 \mathrm{~m}) \\
\text { 空腸, } \\
\text { 上行結腸吻合 } \\
\text { 直腸空置・・ } \\
\text { 人工肛門 }\end{array}$ & $\begin{array}{c}\text { 入院51日 } \\
\text { 生存 }\end{array}$ \\
\hline $\begin{array}{l}\text { (8) } \\
\text { M. H. } \\
\text { (57. } \\
\end{array}$ & $\begin{array}{c}\text { 外傷性横行結腸破裂 } \\
(2 \times 6 \mathrm{~cm}) \\
\end{array}$ & $\begin{array}{l}(H) \\
(-)\end{array}$ & 5 & $100 / 60$ & 6.0 & 7.7 & $\begin{array}{l}\text { 切除術 } \\
\text { 盲腸瘦 }\end{array}$ & $\begin{array}{c}\text { 入院 } 40 \text { 日 } \\
\text { 生存 }\end{array}$ \\
\hline $\begin{array}{lll}\text { (9) } & & \\
\text { H. T. } & 67 & \text { 男 } \\
\end{array}$ & $\begin{array}{l}\text { S状結腸穿孔性腹膜炎 } \\
\text { 大動脈溜の胸膜下牚破 } \\
\text { (大腸フォイハー) }(1 \times 2 \mathrm{~cm}) \\
\end{array}$ & $\begin{array}{l}(H) \\
(H)\end{array}$ & 25 & $130 / 90$ & 5.6 & 3.3 & $\begin{array}{l}\text { 部分切除 } \\
\text { 誘導 } \\
\end{array}$ & $\begin{array}{c}\text { 術後 } 6 \text { 日 } \\
\text { 死亡 }\end{array}$ \\
\hline$\stackrel{(10)}{\text { Y. }} \underset{(58.76}{H} .76$ 女 & $\begin{array}{l}\text { S 状結腸穿孔(盲腸癌) } \\
\left(\mathrm{H}_{0} \mathrm{P}_{0} \mathrm{~S}_{3} \mathrm{~N}_{2} \mathrm{Stage} \mathrm{N}\right) \\
(大 \text { 腸ファイベー) }(1.5 \times 2 \mathrm{~cm})\end{array}$ & $\begin{array}{l}\text { (H) } \\
(\text { (H) }\end{array}$ & 4 & $150 / 70$ & 5.1 & 8.3 & $\begin{array}{l}\text { 右半結腸切除 } \\
\text { 穿孔部閉鎖 }\end{array}$ & $\begin{array}{c}\text { 入院38日 } \\
\text { 生存 }\end{array}$ \\
\hline
\end{tabular}


表 4 外傷性結腸・直腸穿孔・破裂の症例（2）

\begin{tabular}{|c|c|c|c|c|c|c|c|c|}
\hline 氏名 $\frac{\text { 年 }}{\text { 齢 }}$ & 手 術 䛦 断 & $\begin{array}{l}\text { 腹膜炎症状 } \\
\begin{array}{c}\text { 将所見 } \\
\text { (free Gas) }\end{array}\end{array}$ & \begin{tabular}{|c|} 
発症 \\
(時間) \\
\end{tabular} & (mmHg) & $\operatorname{TP}_{(\mathrm{g} / \mathrm{dl})}$ & $\begin{array}{c}W \\
\left(\times 10^{3}\right)\end{array}$ & 手術方法 & 予 後 \\
\hline 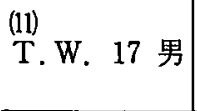 & $\begin{array}{l}\text { 直腸穿孔(Rb) } \\
\text { 異物(筆)挿入 }\end{array}$ & $\begin{array}{l}(+) \\
(-)\end{array}$ & 49 & $108 / 68$ & 8.4 & 13.0 & $\begin{array}{l}\text { 直腸ブジ- } \\
\quad \text { 挿入 }\end{array}$ & $\begin{array}{c}\text { 入院21日 } \\
\text { 生存 }\end{array}$ \\
\hline$\stackrel{(12)}{\mathrm{F} . \mathrm{M} .} \underset{(59.12)}{28}$ & $\begin{array}{l}\text { 直腸穿孔(Ra) } \\
\text { 貧孔性虫垂炎術後の } \\
\text { シリコンる穿孔 }\end{array}$ & $\begin{array}{l}( \pm C \\
(-)\end{array}$ & 非手術 & $120 / 60$ & 7.8 & 7.2 & 誘遒 & $\begin{array}{c}\text { 入院20日 } \\
\text { 生存 }\end{array}$ \\
\hline$\stackrel{(13)}{\text { M. H. }} \underset{(61.33}{73}$ 女 & 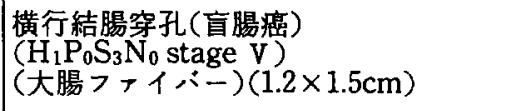 & $\begin{array}{l}(+) \\
(-)\end{array}$ & 5 日 & $130 / 80$ & 6.4 & 4.6 & $\mid \begin{array}{c}\text { 右半結腸切除 } \\
\text { 誘樽 }\end{array}$ & $\begin{array}{c}\text { 術後13日 } \\
\text { 死亡 }\end{array}$ \\
\hline $\begin{array}{l}\text { M.14). T. } 73 \text { 男 } \\
\text { (61. 9) }\end{array}$ & 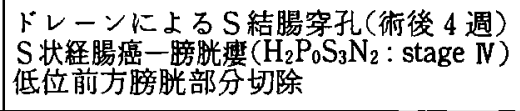 & $\begin{array}{c}(+) \\
\text { (麻孔造影) }\end{array}$ & 非手術 & $112 / 60$ & 5.3 & 10.7 & $\begin{array}{c}\text { 洗浄 } \\
\text { 持続吸引 }\end{array}$ & $\begin{array}{l}60 \text { 日 } \\
\text { 死亡 }\end{array}$ \\
\hline$\stackrel{(15)}{\text { B. M. }} \underset{\text { (62. }}{52}$ 男 & $\begin{array}{l}\text { 外傷性空腸 }(3 \times 0.5 \mathrm{~cm}) \\
\mathrm{S} \text { 状結腸穿孔 }(2 \times 1 \mathrm{~cm})\end{array}$ & $\begin{array}{l}(+) \\
(+)\end{array}$ & 13 & $104 / 84$ & 7.7 & 27.4 & $\begin{array}{c}\text { 縫合閉鎖 } \\
\text { 誘導 }\end{array}$ & $\begin{array}{c}\text { 入院21日 } \\
\text { 生存 }\end{array}$ \\
\hline 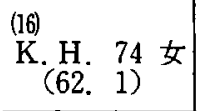 & $\begin{array}{l}\text { 直腸・S結腸穿孔 } \\
\text { 視鏡的尗少（長径 } 4.8 \mathrm{~cm}) \\
\text { 切除術後, 糖承病 }\end{array}$ & $\begin{array}{l}(+1) \\
(-)\end{array}$ & 14 & $100 / 60$ & 6.7 & 18.5 & $\begin{array}{c}\text { 楔状切除 } \\
\text { 誘導 }\end{array}$ & $\begin{array}{c}\text { 入院19日 } \\
\text { 生存 }\end{array}$ \\
\hline$\stackrel{(17)}{\mathrm{E} . \mathrm{K} .} \underset{(63 .}{56})$ & $\begin{array}{l}\text { S状結腸穿孔 } \\
\text { 呕気, 腰痛 } \\
\text { (大腸フフイー゙ー) }\end{array}$ & $\begin{array}{l}(+) \\
(+)\end{array}$ & 18 & $108 / 46$ & 6.2 & 20.1 & $\begin{array}{l}\text { 切除術 } \\
\text { 誘導 }\end{array}$ & $\begin{array}{c}\text { 入院 } 6 \text { 力月 } \\
\text { 生存 }\end{array}$ \\
\hline
\end{tabular}

大腸ファイバー・浣腸・手術時の留置ドレーンなどに よる医原性である例などいろいるな外力による発病例 がある。

\section{a）外傷性穿孔例}

本来の外傷による穿孔・破裂は 8 例である.

症例 1 は31歳男性で作業中鉄の棒が肛門の外側 3 時 方向から刺入して直腸・S 状結腸を貫いた抗創の例で ある. 症例 2 は19歳男性で雨の中を山で測量中転んで 篠竹の切り株が肛門の10時方向から直腸と膀胼を貫い た. 症例 $3 \cdot 4 \cdot 7 \cdot 8 \cdot 15$ は交通事故に上る損傷例 である.

本来の外傷が原因であるこれらの症例では手術まで の時間的経過が概して短かく，污染の程度も少なくて 救命率が高い，小腸や他葴器損傷を合併した例もある が 8 例の全例が生存した。

b）医原性穿孔例

大腸ファイバーによる穿孔が 6 例である.

症例 5 は75歳男性で内科で検查中の穿孔例である. 手術時の状態も悪く, 癌の進行程度 $\left(\mathrm{H}_{0} \mathrm{~S}_{2} \mathrm{P}_{0} \mathrm{~N}_{1}\right.$ : Stage III) からも切除不能と判断して人工肛門造設に 終った。腫瘤は S 状結腸にあり穿孔部はその肛門側で ある.

症例 9 は67歳男性で胸痛・腹痛など不定愁訴のため, 放射線科で検查中大腸ファイバーで $\mathrm{S}$ 状結腸穿孔を
起こした。縫合閉鎖術を行ったが術後 6 日で死亡した。 剖検の結果原疾患は胸部大動脈瘤が右肺胸膜下へ穿破 していた。

症例10は76歳女性で内科での大腸ファイバー検査中 にS 状結腸を穿孔した。手術時に盲腸癌 $\left(\mathrm{H}_{0} \mathrm{P}_{0} \mathrm{~S}_{3} \mathrm{~N}_{2}\right.$ : Stage IV) を認め, 右半結腸切除術と穿孔部の縫合閉 鎖術・浄浄・誘導を行った。症例13は73歳女性で大腸 ファイバー施行中横行結腸を穿孔した。既往歴に結核 性腹膜资があり，遊離ガスは陰性，白血球增多むなく (4600), 発病 5 日目に紹介された。盲腸癌 $\left(\mathrm{H}_{0} \mathrm{P}_{0} \mathrm{~S}_{3}\right.$ $\mathrm{N}_{0}$ : Stage III) で右半結腸切除術を行ったが術後13日 に死亡した。症例16は74歳女性で内視鏡的に直腸と S 状結腸移行部の大きなポリープ（直径 $4.8 \mathrm{~cm}$ )を切除し た後の腹膜炎の症例である.

大腸ファイバー操作中の穿孔は突然の痛みに始まっ て、レントゲン的に 6 例中 5 例に遊離ガスが著明（気 腹)である、検查前の処置が行われているので賽便の 貯溜は少ない。手術までの時間の長かった症例 $9 \cdot 13$ の 2 例以外は救命し得た.

次の 3 例は浣腸やドレーンが原因である。症例 6 は 76歳男性, 自宅で人工肛門からの浣腸操作に上る穿孔 である。症例12は28歳男性, 虫垂穿孔性腹膜炎手術例 で局所とDouglas 窩に誘導を行った。術後 2 週頃から 便臭を感じた。シリコン・ドレーンによる直腸の正迫 
表 5 結腸・直腸の原因別穿孔・破裂部位

\begin{tabular}{|c|c|c|c|c|c|c|c|}
\hline 原因 & 盲腸 & 上行結腸 & 横行結腸 & 下行結腸 & $S$ 状結腸 & 直 腸 & 計 \\
\hline I. 特発性 & 0 & 0 & 0 & 0 & 9 & 1 & 10 \\
\hline II. 続発性 & 3 & 1 & 0 & 0 & 4 & 2 & 10 \\
\hline III. 外傷性 & 0 & 0 & (3) & 0 & $\left(\begin{array}{l}11 \\
(5)\end{array}\right.$ & 4 & 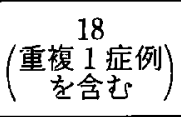 \\
\hline 計 & 3 & 1 & 3 & 0 & 24 & 7 & 38 力所 \\
\hline
\end{tabular}

穿孔が瘦孔造影で確認された。管状瘦で， 3 週後に自 然治瘾した。症例14は73歳男性で S 状結腸癌による S 状結腸膀脱瘦の根治手術例でドレーンの王迫で吻合部 より口側 $5 \mathrm{~cm} の \mathrm{~S}$ 状結腸に穿孔を生じて後腹膜腔に 膿瘍を形成した。シリコン・ドレーンは材質が硬いの で，その後はペンローズ・ドレーンを使用している。

\section{II. 結腸 ・直腸穿孔の部位と大きさ}

経験した37例の穿孔・破裂の部位を原因別に表 5 に 示した. 特発性穿孔10例中 $S$ 状結腸が 9 例, 直腸は $\mathrm{Ra}$ の部分に 1 例のみである。続発性穿孔10例中 S 状結腸 か 4 例，盲腸に 3 例，直腸に 2 例，上行結腸に 1 例で ある。外傷性穿孔では18個所中 S 状結腸に11例, 横行 結腸 3 例，直腸 4 例である。横行結腸 3 例のらち 2 例 は外傷性で脊椎との間に挾まれての穿孔・破裂例で他 の 1 例は大腸ファイバーによる穿孔である. 全体を通 じて S 状結腸が38個所の穿孔中24個所（63.2\%）と王 倒的に多い. 穿孔の大きさは pinhole から $3 \times 3 \mathrm{~cm}$ とい ろいろである。

\section{III. 臨床症状と診断}

穿孔の大きさはまちまちで，さらに発症から手術ま での時間によっても症状がことなる，污染の比較的少 ないものから，大きく破れて便で污染の激しいものま である．腹膜炎の症状は強い例が多い，レントゲン的 に腹腔内遊離ガス像の証明できる頻度は必ずしも多く ない，特発性穿孔例では10例中 5 例 $(50 \%)$ ，続発性穿 孔例では10例中 7 例 (70\%), 外傷性穿孔の17例では 8 例 $(47 \%)$ である。

発病から手術までの時間は3 時間程の短い例から2 日位までである。

膿瘍形成など不定な愁訴となった例もある。

白血球数が 4000 以下の症例が 6 例もみられたことに
は注意が必要である。血清蛋白が $6.5 \mathrm{~g} / \mathrm{dl}$ 以下である 例が37例中25例 $(67.6 \%)$ で，最高血圧が $100 \mathrm{mmHg}$ 以 下の例が37例中15例 (40.6\%) と状態の悪い例が多く， 手術適応を決めるのに大切なことである，高齢者の多 くなっている現在，排便時の努責後に疼痛で始まった 4 例のあったことも注意すべきことである。

\section{IV. 細菌学的検討}

開腹手術にさいして菌の培盖・検索の行われた症例

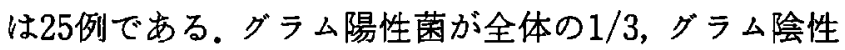
菌が約 $2 / 3$ を占める。他に真菌の candida albicans が 2 例(3.2\%)含まれた。菌検出の成績を表 6 に示した。

表 6 結腸・直腸穿孔・破裂例での細菌検出成績（培 養25例)

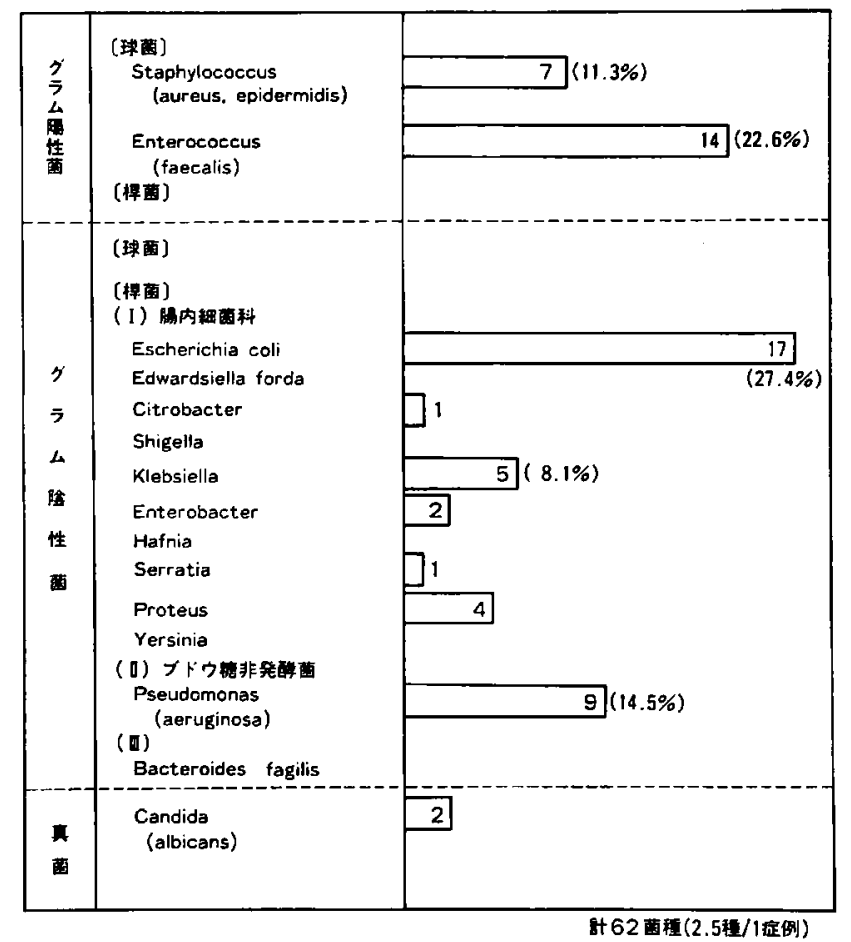


グラム陽性菌では staphylococcus (aureus epidermidis) $11.3 \%$, enterococcus (faecalis) $22.6 \%$, ஜ ラム陰性悍菌では escherichia coli $27.4 \%$, klebsiella $8.1 \%$, psudomonas (aeruginosa) $14.5 \%$, proteus $6.4 \%$ みられた。

全体では62種類の菌が検出されていて，1症例あた り2.5種の複数菌の感染ということになる. 最近, 経過 の長期例では多剤耐性黄色ブドウ球菌の出現をみやす い.

\section{V. 結腸穿孔性腹膜炎の予後}

1）治療の困難性と死亡率

結腸・直腸穿孔性腹膜炎患者の来院時の全身状態は 悪いことが多い，前項で細菌培養の結果を示したよう に，複数菌感染であることが多く，悪循環をきたして DIC・MOFなどへ移行して治療に難涉する例が多く経 験された。われわれが経験した37症例には10例 (27.0\%)の死亡をみた。死亡例は手術後 3～9 日（平 均7.9日）が多く，長い例では27日後・44日後など悪戦 苦闘の末の死亡である。

2）他部位の消化管穿孔例の死亡率との比較

今回, 結腸・直腸穿孔の症例を検討した昭和 45 年 4 月から平成元年 3 月までの同期間中に経験した他部位 での消化管穿孔性腹膜炎の例での死亡率を比較した (表 7 ).

（a）胃・十二指腸潰瘍穿孔性腹膜炎

胃・十二指腸潰瘍手術例の総数 779 例中穿孔例は 155 例 (19.9\%) で， 5ち死亡例は 6 例 (4.3\%) である.

（b）小腸穿孔性腹膜炎

小腸切除となった症例は外傷を除いて，鼠径へルニ 了嵌頓54例中の穿孔 5 例，5ち死亡は 1 例 (1.9\%)， 大腿へルニフ嵌頓 25 例中穿孔のため腸切除が行われた 12例では死亡 2 例 $(8.0 \%)$, 閉鎖孔へル =フ嵌頓 5 例

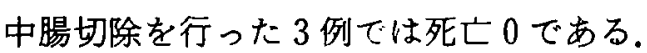

表 7 消化管案孔性腹膜炎での死亡率

(昭和 45 年 4 月～平成元年 3 月)

\begin{tabular}{|c|c|c|c|}
\hline & 手術総数(例) & 穿孔例 (\%) & 死亡例(\%) \\
\hline 胃 -十二指腸㵋㿋 & 779 & $155(19.9)$ & $6(4.3)$ \\
\hline (小 腸) & & & \\
\hline 鼠恁へル & $54 / 1301$ & $5 / 54(9.3)$ & $1(1.9)$ \\
\hline 大郎 ヘルニア嵌頓 & $25 / 74$ & $12 / 25(48.0)$ & $2(8.0)$ \\
\hline 閉鎖孔ール = ア嵌頓 & $5 / 5$ & $3 / 5(60.0)$ & $0(0)$ \\
\hline 急性虫垂炎 & 2,430 & $359(14.8)$ & 0 \\
\hline 結腸 - 直腸穿孔 & & 37 & $10(27.0)$ \\
\hline
\end{tabular}

（c）虫垂穿孔性腹膜炎

急性虫垂炎 2,430 例中穿孔性腹膜炎は359例(14.8\%) であるが死亡例は 0 である。

すなわち，結腸・直腸穿孔性腹膜炎の死亡率 $27 \%$ は 消化管穿孔性腹膜炎の中では著しく予後の悪いことが 知れた。

\section{考 察}

I. 結腸・直腸穿孔の原因・誘因別分類に関する考察 結腸・直腸穿孔は上部消化管の穿孔に比べて頻度は 少ない，しかしその原因・誘因は多岐にわたり, 複雑 でその原因別分類にはいろいろの試みい〜7がある.

今回著者らは小暮ら早や，安達ら9)の如〈便宜的に外 傷性・続発性・特発性の 3 つに分けて自験例を検討し た.

\section{1）外傷性穿孔}

交通事故などでの腹腔内損傷の他，刺創・杭創があ る. また大腸ファイバーに上る検查あるいは内視鏡的 切除術，浣腸，留置ドレーンなどによる医原性穿孔な どが含まれる。

飯塚ら $\left.{ }^{10}\right)$ は腹部外傷753例のちち結腸32例, 直腸 3 例 計 35 例で全体の $4.6 \%$ であるとし, 三木ら ${ }^{11}$ は腹部外傷 268例中結腸損傷17例（6.3\%）と報告している。般 外傷による結腸・直腸穿孔・破裂の頻度は必ずしも多 くない，交通事故なとの外傷では春椎との間に挾さま れての挫滅の活らが多く，部位的には横行結腸である ことが多いが，小腸や他䏩器との合併症例むある。

内視鏡による穿孔には技術的な問題は勿論である が，腸管壁自体の病変部位での穿孔と直接病変部でな い, 上り肛門側での穿孔もある。また解剖学的異常や 瘾着などによる挿入困難な場合もみられる。 Andresen $^{122}$ の直腸鏡での穿孔46例の検討では，正常腸 管の穿孔(45\%), 癌の穿孔(28\%)，結腸悡室炎(11\%)， 潰煬性大腸资 ( $6 \%$ )をあげている. 円羽13)のわが国の 全国集計によれば検查総数 54,463 例中68例（0.12\%） である。

アメリカ内視鏡学会の調査では25,298例中50例 (0.19\%)である. polypctomyを同時に行ったもので は6.214例中20例 $(0.32 \%)$ である ${ }^{14)}$.

\section{2) 特発性穿孔}

報告者によって特発性の定義が少しずつ異なってい る. Brearley ${ }^{151}$ は外力なしに起こる穿孔を spontane-

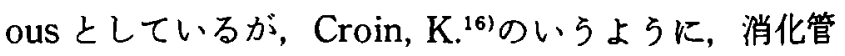
破裂の場合 spontaneousという語はしばしぱ, idiopathic と同意語とされている。 
Noussius ${ }^{17}$ はなんら認むべき病変のない場合を idiopathic ruputur とよんで，なんらかの病变のある 場合を spontaneous ruputer として区別している.

しかし正常と思われていた腸管が破れる機序に関し ての説明は末だよく知られていない。

(a) 䄸室穿孔

大腸頽室の穿孔と診断される例の報告は従来外国に 多かったが，近頃ではわが国にも散見される。小暮ら の特発性とした症例の中にも組織学的に S 状結腸覟 室の穿孔とみている例がある。橋本ら ${ }^{181}$ は自験大腸穿 孔18例の検討の中に息室穿孔の 5 例をあげ，紙田ら ${ }^{19)}$ は結腸秝室穿孔の男性 2 例，女性 4 例，平均年跉73.5 歳の 6 例を検討して報告している。また緊急手術を要 した結腸䄸室症を検討した鈴木ら ${ }^{201} は 6$ 年間に経験し た結腸㮩室376例中手術例は32例で，らち緊急手術の21

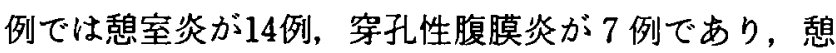
室全体としては右側に多いが緊急手術例は左側に多い ことを指摘している．外国例では Gennaro ${ }^{21)}$ が馣室症 500 例の観察中 4 例 (0.8\%) の穿孔，Bockus は $2.5 \%$, と報告している。

（b）宿便性穿孔

外国で報告のある宿便性穿孔 stercoraceous perforation む原因不明のまま特発性の項に入れているこ とが多い。自験例では排便・怒責後の痛みで発病した 男子老人の 4 例があった。 Brearley ${ }^{15}$ 便い便塊が腸 管壁の ischemic necrosis を引き起こす衝撃になる可 能性があるとしている。

3）続発性大腸穿孔

結腸壁になんらかの器質的变化，例兄ば悪性腫汮の 浸潤・潰瘍・狭窄あるいは炎症性变化で穿孔をきたす。

(a) 癌による穿孔

同期間における著者らの経験した結腸癌手術例は 177例で，5ち穿孔は 3 例（1.7例），直腸癌は141例中 穿孔は 1 例 (0.7\%) であるから多い頻度ではない。胃 癌は632例中穿孔は 4 例でさらに少ない。

本邦の大腸穿孔報告例（1926年～1972年）を集計し た加藤ら゙作によれば癌腫 37 , 穿孔性壊疽性結腸炎 13 , 潰 湯性大腸炎 6 , 細菌性赤莉 5 , 腸結核 4, ベーチェッ

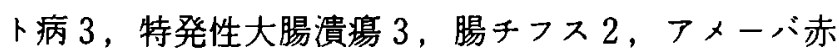
琍 2 , 腸重積 1 , 軸捻転 1 , 細網肉腫 1 をあげている. 小暮ら ${ }^{8)}$ は大腸癌348例中19例 (5.4\%), Crowder ${ }^{22)}$ は 大腸癌1,678例で $2.6 \%$, Mersheimer ${ }^{231}$ は大腸癌709例 中22例 (3.1\%) と報告している。

Donaldson ${ }^{24)}$ は 20 年間に経験した大腸癌 2,354 例中
穿孔が182例 (7.8\%) としたが，穿孔の type としては

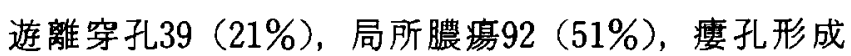
50 (28\%) で穿孔部位としては上行結腸42（23\%）, 横 行結腸 12 (12\%)，下行結腸188（65\%)をあげている. 大腸癌の穿孔 14 例を検討した高橋ら $\left.{ }^{25}\right)$ にると 10 年間 の大腸癌手術は 381 例 $(3.7 \%)$ で遊離穿孔 6 例, 膿瘍 形成 8 例である。同様に大石ら ${ }^{261}$ は 10 年間の大腸癌穿 孔13例をあげ, 癌の口側穿孔は S 状結腸と直腸に多く 全周性浸潤をもつ症例に多く, 口側穿孔では遊離穿孔， 腫瑒部穿孔では被覆穿孔が多いといら。

（b）潰煌性大腸炎による穿孔

著者らは35歳男性の症例を経験した。

宇都宮ら ${ }^{27)}$ 報告では, 本邦の疫学調査によると潰 場性大腸炎之診断され，登録されている患者4,484例の 5ち外科手術の行われた患者は640例 (14.3\%) で死亡 は103例（16.1\%）である。緊急手術144例中大出血 34 例 $(23.6 \%)$, 穿孔性腹膜炎は31例 $(21.5 \%)$, 中毒性 巨大結腸35例（24.3\%）などである.

(c) 直腸子宮内膜症に上る穿孔

婦人科領域では子宮内膜症はよく遭遇する疾患であ るが，それは主として性器内内膜症である。本論文で 報告した直腸子宮内膜症は，本邦では木村の報告例に 始まって豊島ら ${ }^{28)}$ の報告後を集めて30例をみるが，子 宮内膜症での直腸穿孔例は自験例以外にみられなかっ た.

\section{結語}

1）昭和 45 年 4 月から平成元年 3 月までの 19 年間に 結腸・直腸穿孔性腹膜炎 37 例を経験した。原因別に特 発性・続発性・外傷性に分類して検討した。

2）特発性穿孔とした10例の中には䕀室が原因と思 われた例もある。比較的高齢者に多い．排便・努責後 に発症した 4 例がある. 欧米の報告にみる宿便性穿孔 の発生機序も未確定なのでこの項へ入れた。

3）続発性穿孔は10例である. 結腸・直腸癌の 4 例や 漬汮性大腸炎の穿孔例, 直腸子宮内膜炎に上る直腸穿 孔の極く稀な例も経験された。

4）外傷性穿孔は17例である。本来の外傷に上る穿 孔・破裂の 8 例の他に大腸ファイバー検查中の穿孔 6 例, 術後に留置したドレーンの圧迫による穿孔 2 例, 人工肛門造設例での浣腸が原因の1例など医原性穿孔 の 9 例がある。

5）結腸・直腸穿孔の部位は特発性穿孔10例中 9 例が $\mathrm{S}$ 状結腸, 直腸が 1 例である。続発性穿孔の10例では $\mathrm{S}$ 状結腸 4 例, 盲腸 3 例, 直腸 2 例, 上行結腸 1 例であ 
る. 外傷性穿孔の17例では S 状結腸11例, 横行結腸 3

例，直腸 4 例である. 全体を通して38筒所の穿孔中 24 個所 $63.2 \%$ S 状結腸であった。

6）臨床症状は穿孔の大きは, 発症から手術迄の時間 によって症状の重篤さがことなる。

診断ではレントゲン的に遊離ガス陽性例は特発性は 10 例中 5 例 $(50 \%)$, 続発性は10例中 7 例 $(70 \%)$, 外 傷性は 17 例中 8 例（47\%）である。白血球増多のない 例が37例中 6 例 $(16.2 \%)$ ある。血清蛋白 $6.5 \mathrm{~g} / \mathrm{dl}$ 以 下であった37例中 25 例 (67.6\%)は収縮期血圧 $100 \mathrm{~mm} /$ $\mathrm{Hg}$ 以下であることなどとともに全身状態の悪いこと が知れた。

7）細菌学的検索の行われた25例では62種の菌が検 出された。 1 例平均 2.5 種の複数菌感染である. DIC・ MOFなどに移行して治療に難涉する例が多く経験さ れた。

8）結腸・直腸穿孔とその他の消化管穿孔での死亡率 を同じ期間の症例で検討した。

胃・十二指腸潰瘍779例中穿孔の155例（19.9\%）で の死亡は 6 例 $(3.8 \%)$, 鼠径へルニフ手術 1,301 例中嵌 頓は54例でそのうち，穿孔の 5 例に小腸切除して死亡 1 例 $(20 \%)$, 大腿へル =ア手術74例中嵌頓は25例 (33.8\%) で穿孔の12例で小腸切除して死亡 2 例 $(16.7 \%)$ ，閉鎖孔へルニフ嵌頓の 5 例中小腸切除され た 3 例では死亡 0 である。

すなわち結腸・直腸穿孔の術後は難沾することも多 く, 37例中死亡10例 (27\%) と著しく悪い成績である.

\section{文献}

1）坂部孝, 依光好一郎, 山形省吾他：特発性大腸穿 孔，外科 $32: 684-692,1970$

2) Havia $T:$ Non-traumatic perforation of the colon. Acta Chir Scan 137: 375-379, 1971

3) Floyd RD, Griffen WO: Colonic diverticular disease : Changing operativ management. Ann Surg 137: 979-982, 1971

4）下山孝俊, 池田敏明, 下田穂積他：大腸穿孔につい て, 外科 $35: 843-849,1972$

5) Huttumen RT, Heikkinen LE, Räsänen $O$ : Free perforation of the colon. Acta Chir Scand $140: 535-541,1974$

6）加藤祐之助, 小林一雄, 小野田㹂他：大腸穿孔一教 室で経験した12例と本邦報告194例の検討, 日本大 腸肛門病会誌 $29: 4-14,1976$

7) 三村一夫, 高橋 裕, 平山星夫他 : 大腸穿孔, 救急
医 8:707-714, 1984

8）小暮公孝, 中村卓次：大腸穿孔の臨床, 外科 40 : $732-740,1978$

9）安達 亘, 三輪裕通, 高橋千治他：下部消化管穿孔 例の検討，日臨外医会誌 $49: 1176-1182,1988$

10）飯塚 積：腹部外傷一統計を中心に一。災害医 $10: 744-749,1967$

11）三木輝雄：腹部外傷一下部腸管損傷を中心に一, 災害医 $10: 715-722,1967$

12) Andersen AFR: Perforation from proctoscopy. Gastroenterology $9: 32-43,1947$

13）円羽寛文：大腸ファイパースコープ㭘査の偶発 症, フンケート調查による全国集計, Gastoroenterol Endosc 21:178-192, 1979

14）須川暢一：内視鏡による合併症（1974年度フメリ 力内視鏡学会調查), 胃と腸 $11: 657-661,1976$

15) Cronin $K$ : The problem of spontaneous rupture of alimentary canal. Brit J Surg $47: 43$ $-50,1959$

16) Noussias MP: Spontaeous ruptur of the bowel. Brit J Surg 50 : 195-198, 1962

17) Brearley RMB: Spontaneous perforation of the colon, due to alkaline medication. Brit Med J $1: 743,1954$

18）橋本忠明, 溥 伸三, 勝部宿二他：教室における大 腸穿孔18例の検討，日臨床外医科会誌 $39 ： 363$ $-367,1978$

19）紙田信彦，山口善友, 金井正男他：結腸憩室穿孔例 の検討，外科診療 $21: 1116-1119,1979$

20）鈴木啓子, 村瀬 茂, 中島 清他：緊急手術を要し た結腸䅗室症の検討，日救急医会関東誌 $9 ： 172$ $-173,1988$

21) Gennaro AR, Rosemand GP: Diverticulitis of the colon. Dis Col Rect $17: 74-81,1974$

22) Crowder VH, Cohn I: Perforation in cancer of the colon and rectum. Dis Colon Rect 10: 415 $-420,1967$

23) Mersheimer WL, Willer EM : Diffuse peritonitis secondary to intestinal perforation complicating malignant. Surg Gynecol Obstet 99 : 436-440, 1954

24) Donaldson GA: Themanagement of perforative carcinoma of the colon. New Engl J Med $258: 201-207,1958$

25）高橋勝三, 畑尾正彦, 栗栖 茜他: 大腸癌穿孔14例 に関する考察，救急医 $10: 345-350,1986$ 
26）大石英人, 今 真人, 神崎 博他：大腸癌に起因す る穿孔性腹膜炎症例の険討, 日救急医会関東誌 $8: 601-608,1988$

27）宇都宮利善, 鉿木紘一，篠原 央他：潰湯性大腸资 の外科療法, 日本大腸肛門病会誌 $52 ： 64-75$,
1989

28）豊島 宏, 板東隆文, 渡辺 昇他：腸管子宮内膜症 について一自験 5 症例と本邦報告例の検討，日本 大腸肛門病会誌 $34: 1-9,1981$

\title{
A CLINICAL STUDY OF 37 CASES OF PERFORATION OF THE COLON AND RECTUM
}

\author{
Shoichi AIBA, Hidero SHIOZAKI, Hiroshi MATSUMOTO, Toshiro IKEYA, Satoshi NAKAMURA, \\ Osamu UCHIDA, Masaru IZUMI, Hiroyuki TAKEI and Tooru WATANABE \\ Department of Surgery, Maebashi Red Cross Hospital \\ Sachio MIYAMOTO, Yoshifumi TANAHASHI and Fujio MAKITA \\ Second Department of Surgery, School of Medicine, Gunma University
}

Perforation of the colon and rectum is rarely found as compared with those of the upper digestive organs. Nevertheless it has a variety of etiologic factors, causes, and the sites of perforation, and often leads to severe outcomes such as fecal peritonitis.

The authors conducted a retrospective study of 37 cases of the disease experienced at our department during a 19-year period since April 1970 to compare for the diagnosis, clinical course, and prognosis by causes. Ten cases diagnosed as idiopathic perforation involved 4 which might be of perforation of the diverticulum or developed in aged patients after evacuation or violent emotion such as anger. Another 10 cases of secondary perforation were comprised of 4 of colorectal carcinoma, 3 of intestinal obstruction, and very rare 2 cases of ulcerative colititis and rectal endometriosis perforations. Traumatic perforation was found in 17 cases, of which 8 were caused by trauma and 9 , by medical treatment. In these patients, an average of 2.5 kinds of bacteria by each case was isolated. Such multi-infection makes the treatment difficult and the mortality increase. The mortality was compared with those of perforations at other sites of gastrointestinal organs during the same period. In addition, a review of foreign and domestic literature is described. 